\title{
Exocytotic protein components in rat pituitary gland after long-term estrogen administration
}

\author{
G Majó, M J Lorenzo ${ }^{1}$, J Blasi and F Aguado \\ Laboratori de Neurobiologia Cel.lular i Molecular, Departament de Biologia Cel.lular i Anatomia Patològica, Facultat de Medicina, Universitat de Barcelona; \\ Hospital de Bellvitge, Feixa Llarga s/n, L’Hospitalet de Llobregat 08907, Barcelona, Spain \\ ${ }^{1}$ Departamento de Bioquímica y Biología Molecular, Universidad de Alcalá, Alcalá de Henares, Spain \\ (Requests for offprints should be addressed to F Aguado, Departament de Biologia Cel.lular i Anatomia Patológica, Campus de Bellvitge, Facultat de Medicina, \\ Universitat de Barcelona, c/Feixa Llarga s/n, 08907 L'Hospitalet de Llobregat, Spain) \\ (F Aguado is now at Departament de Biologia Cel.lular Animal i Vegetal, Facultat de Biologia, Av. Diagonal 645, 08071 Barcelona, Spain)
}

\begin{abstract}
Recently, a set of proteins involved in the docking and fusion machinery of secretory organelles has been identified in anterior pituitary cells. In this study we analyzed, by Western blotting and immunocytochemistry, the expression of several proteins involved in exocytosis after long-term administration of $17 \beta$-estradiol $\left(\mathrm{E}_{2}\right)$ in Fischer 344 rats. No differences were observed in the amount of synaptosomal-associated protein of $25 \mathrm{kDa}$, synaptobrevin 2 , syntaxin 1 , synaptotagmin I and Rab3a in total brain homogenates from treated rats after $\mathrm{E}_{2}$ administration. In striking contrast, the levels of all of these exocytotic
\end{abstract}

proteins, including cellubrevin, were notably decreased in pituitary glands of $\mathrm{E}_{2}$-treated rats. In addition, no differences were observed in the in vitro basal and 8-Br-cAMPinduced prolactin (PRL) release between pituitary cells from control and $\mathrm{E}_{2}$-treated rats, whereas TRH-induced PRL release in anterior pituitary cells from $E_{2}$-treated animals was higher than in control donors. In conclusion, this study shows that protein components of the exocytotic machinery are specifically down-regulated in the pituitary gland of $\mathrm{E}_{2}$-treated Fischer 344 rats.

Journal of Endocrinology (1999) 161, 323-331

\section{Introduction}

In regulated exocytosis, secretory vesicles fuse with the plasma membrane in response to a physiological stimulus. Neuronal and endocrine cells are highly specialized cells that release their chemical signals for intercellular communication by regulated exocytosis. Membrane depolarization or the action of a secretagogue usually induces a transient rise in cytoplasmic calcium concentration, which triggers exocytosis (Burgoyne \& Morgan 1993).

Insights have recently been made into the molecular mechanisms underlying exocytosis in neuronal cells. A set of proteins involved in the docking and fusion of the two neuronal secretory organelles (synaptic vesicles and large dense-cored vesicles) has been identified. Some of these synaptic proteins, like synaptosomal-associated protein of $25 \mathrm{kDa}$ (SNAP-25) and syntaxin, are located at the plasma membrane, whereas others, such as synaptobrevin, synaptophysin, Rab3A, synapsin and synaptotagmin, are located on synaptic and large dense-cored vesicle membranes (for review see Südhof 1995, Linial \& Parnas 1996). In addition, the soluble proteins $\mathrm{N}$-ethylmaleimide-sensitive fusion protein (NSF) and soluble NSF attachment protein (SNAPs) are essential for membrane trafficking (Rothman 1994). According to the SNAP receptors (SNARE) hypothesis, a suitable interaction between plasma membrane proteins (t-SNAREs: SNAP-25 and syntaxin) and vesicular membrane proteins (v-SNAREs: synaptobrevin) with the soluble factors (NSF and SNAPs) is essential for the initiation of the fusion process (Söllner et al. 1993a,b, Rothman 1994). Moreover, the identification of isoform families of most synaptic proteins, including non-neuronal isoforms (e.g. cellubrevin as a synaptobrevin isoform), provides a further level of complexity (Linial 1997).

Many of the above proteins were originally identified as neuronal-specific components due to their abundant expression in nervous tissues. However, a functional role for these proteins and their non-neuronal isoforms has been proposed in different endocrine cell types (Lang et al. 1997, Morgan \& Burgoyne 1997). These molecular components of the exocytotic machinery have also been identified in anterior pituitary cells (Wendland \& Scheller 1994, Marquéze et al. 1995, Oho et al. 1995, Redecker et al. 1995, Aguado et al. 1996, Jacobsson \& Meister 1996, Majó et al. 1998). In adenohypophyseal cells, t-SNAREs are located at the plasma membrane, and protein components of neuronal secretory organelle membranes are located on hormone-containing secretory granules and synaptic-like microvesicles (SLMV) (Wendland \& Scheller 1994, Aguado et al. 1996, Jacobsson \& Meister 1996, Majó 
Table 1 Primary antibodies used in this study

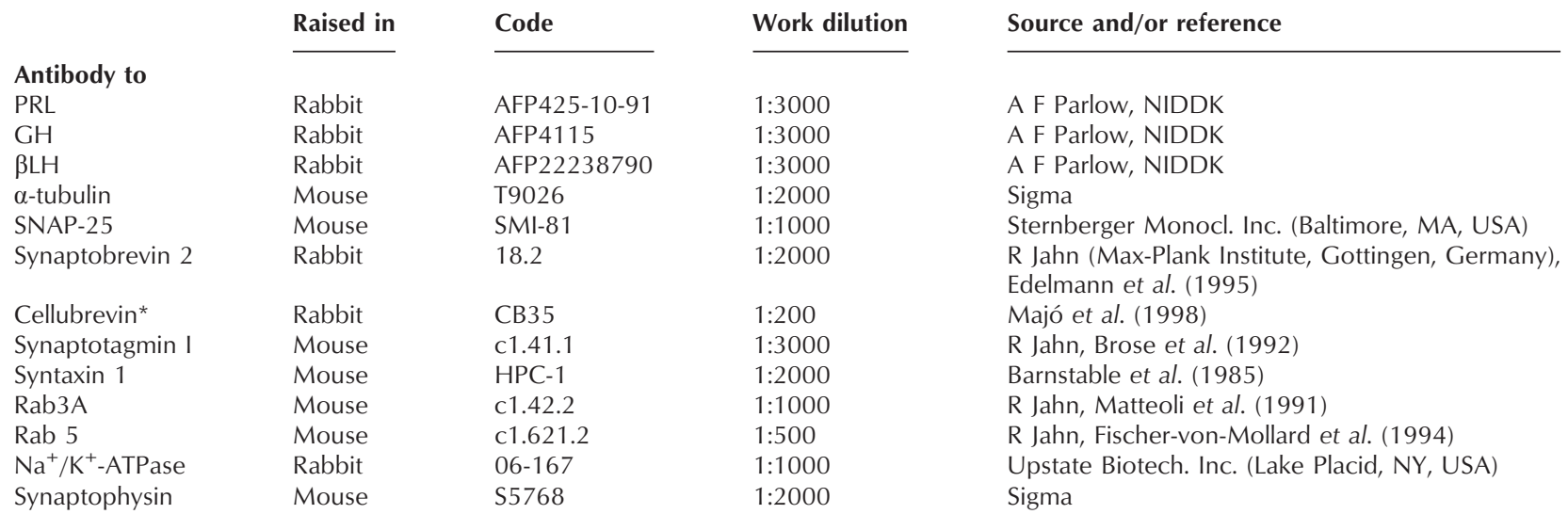

${ }^{*}$ The antibody raised against cellubrevin also recognizes its homolog synaptobrevin.

et al. 1998). It is thought that secretory granules are the counterpart of neuronal large dense-cored vesicles and SLMV of synaptic vesicles (Jahn \& De Camilli 1991). Furthermore, the functional participation of some of these components in pituitary hormone exocytosis has been demonstrated. It has been shown that SNAP-25 is essential in the regulated release of adrenocorticotropin (ACTH) and prolactin (PRL) from AtT-20 and GH3 cell lines respectively (Aguado et al. 1997, Masumoto et al. 1997). In addition, different members of the Rab family are involved in secretory granule localization and calciuminduced exocytosis in anterior pituitary cells (Lledo et al. 1993, Nsee et al. 1993, Lledo et al. 1994, Perez et al. 1994).

It has been shown that SNAP-25 is overexpressed in human PRL cell adenomas (Majó et al. 1997). Since prolactinomas represent the most commonly occurring type of pituitary tumor in humans (Kovacs et al. 1977), it is important to study the possible regulation and functionality of the exocytotic molecular components in PRLsecreting tumor cells. The aim of this study was to analyze, by Western blotting and immunocytochemistry, the expression of several proteins involved in exocytosis during PRL-cell tumorigenesis induced by long-term 17 $\beta$ estradiol $\left(\mathrm{E}_{2}\right)$ administration in Fischer 344 (F344) rats. In addition, we also compared the PRL secretion rates of control and $\mathrm{E}_{2}$-treated pituitary cells.

\section{Materials and Methods}

\section{Animals}

Adult F344 female rats weighing 130-150 g (Criffa S.A., Barcelona, Spain) were housed in a controlled environment $\left(22^{\circ} \mathrm{C}\right.$; $12 \mathrm{~h}$ light/12 h darkness; 40-60\% humidity) with food and water available ad libitum. Under deep anesthesia (ketamine hydrochloride $20 \mathrm{mg} / \mathrm{kg}$, Parke-Davis, Morris Plains, NJ, USA) 30 animals were ovariectomized bilaterally and implanted subcutaneously with 1-cm silastic capsules (Dow-Corning (Midland, MI, USA); outside diameter, $3.125 \mathrm{~mm}$; inside diameter, $1.875 \mathrm{~mm}$ ) containing $17 \beta$-estradiol (Sigma, St Louis, MO, USA). Thirty-five ovariectomized control rats were implanted with blank silastic capsules. Animal surgery and care were carried out in accordance with the European Community Council Directive (86/609/EEC). Rats were killed at different times from one week up to seven weeks after treatment.

\section{Western blotting analysis}

The rats were decapitated and the pituitaries were excised. After removal of the neurointermediate lobe, the anterior pituitaries were homogenized with $10 \mathrm{mM}$ HEPES $\mathrm{pH}$ 7.4, $1 \mathrm{mM}$ EGTA, and $0.5 \mathrm{mM}$ phenylmethylsulfonyl fluoride (Sigma). Sodium dodecyl-sulfate-polyacrylamide gel electrophoresis $(12 \cdot 5 \%$ SDS-PAGE) was carried out as described by Laemmli (1970) using a mini-protean system (Bio-Rad, Hercules, CA, USA). After electrophoresis, the gels were electrotransferred to nitrocellulose membranes (Amersham Iberica, Madrid, Spain) according to Towbin et al. (1979). The membranes were blocked in a solution consisting of 5\% non-fatty milk powder in TBS $(140 \mathrm{mM}$ $\mathrm{NaCl}, 50 \mathrm{mM}$ Tris- $\mathrm{HCl} \mathrm{pH} 7 \cdot 4$ with $0 \cdot 1 \%$ Tween-20) for $1 \mathrm{~h}$ at room temperature and then incubated at $4{ }^{\circ} \mathrm{C}$ overnight with the appropriate primary antibody diluted in blocking buffer. The primary antibodies used are shown in Table 1. After several washes with blocking solution, the membranes were incubated for $1 \mathrm{~h}$ with a peroxidaseconjugated secondary antibody, and peroxidase activity was detected using the enhanced chemiluminescent method (ECL, Amersham). 


\section{Immunocytochemistry}

Under deep diethyl ether anesthesia, the rats were perfused through the heart with phosphate-buffered saline (PBS) followed by $4 \%$ paraformaldehyde in $0.1 \mathrm{M}$ phosphate buffer, $\mathrm{pH} 7 \cdot 4$. The pituitaries were removed, post-fixed for $4 \mathrm{~h}$ in the same fixative solution and cryoprotected with $30 \%$ sucrose solution in $0.1 \mathrm{M}$ phosphate buffer at $4{ }^{\circ} \mathrm{C}$ overnight. Sections $(40 \mu \mathrm{m})$ were obtained with a cryostat and collected in PBS. Pituitary sections were soaked for $1 \mathrm{~h}$ in PBS containing 10\% methanol and $3 \% \mathrm{H}_{2} \mathrm{O}_{2}$, washed in PBS and preincubated for $1 \mathrm{~h}$ in $5 \%$ fetal calf serum in PBS containing $0 \cdot 3 \%$ Triton X-100 and $0 \cdot 2 \%$ gelatin. Overnight incubations with the primary antibodies indicated in Table 1 were carried out at $4{ }^{\circ} \mathrm{C}$ in PBS containing $1 \%$ fetal calf serum, $0 \cdot 3 \%$ Triton $\mathrm{X}-100$ and $0 \cdot 2 \%$ gelatin. The immunocytochemical reaction was developed with Vectastain ABC kit (Vector Laboratories, Burlingame, CA, USA). The peroxidase complex was visualized by incubating the sections with $0 \cdot 05 \%$ diaminobenzidine and $0.01 \% \mathrm{H}_{2} \mathrm{O}_{2}$ in PBS. Sections were mounted, dehydrated and coverslipped in DPX. The specificity of the immunoreaction was tested by omitting the primary antibody or by replacing it with an equivalent concentration of non-specific rabbit or mouse immunoglobulin G. No immunostaining was observed in these sections. Double-labeling immunocytochemistry was carried out in sections to detect different proteins and pituitary hormones simultaneously by a combined light microscopic procedure according to Levey et al. (1986). The immunostaining of SNAP-25 was performed using the monoclonal antibody SMI-81, as described above for single labeling studies. After further rinsing, sections were processed to reveal the presence of growth hormone $(\mathrm{GH})$ or PRL using polyclonal antibodies to rat hormones $(1: 1000)$. The immunocytochemical reaction, after peroxidase-anti-peroxidase procedures was developed in a medium containing $0.01 \%$ benzidine dihydrochloride (Sigma) and 0.025\% sodium nitroprusside (Merck, Darmstadt, Germany) in PBS pH 6 for $10 \mathrm{~min}$, and then in the same solution containing $0.05 \% \mathrm{H}_{2} \mathrm{O}_{2}$ until the signal developed. The double labeling was done both ways round with equivalent results.

\section{Primary cell cultures and RIA for PRL}

Short-term pituitary cell cultures were prepared according to a modification of the method of Ben-Jonathan et al. (1983) as described previously (Aguado et al. 1996). Seven weeks after surgery, control and treated ovariectomized animals were decapitated, the pituitary glands were removed and the neurointermediate lobes discarded. After rinsing in Krebs-Ringer's bicarbonate buffer without $\mathrm{Ca}^{2+}$ and $\mathrm{Mg}^{2+}$ (KRBGA), the tissues were cut into small pieces. The fragments were incubated in KRBGA containing $0 \cdot 2 \%$ trypsin (Sigma) for $1 \mathrm{~h}$ in a metabolic incubator at $37{ }^{\circ} \mathrm{C}$ under $\mathrm{CO}_{2}$ and dissociated mechanically by gentle passage through a Pasteur pipette. The tissue suspension was harvested by centrifugation and incubated in KRBGA with DNAase $(1 \mathrm{mg} / \mathrm{ml}$; Sigma) for $5 \mathrm{~min}$. Dispersed individual cells were harvested by centrifugation and resuspended at $37^{\circ} \mathrm{C}$ in Dulbecco's modified Eagle's medium supplemented with 10\% fetal calf serum, $2 \mathrm{mM}$ glutamine, $1 \mathrm{mM}$ sodium pyruvate, penicillin $(100 \mathrm{U} / \mathrm{ml})$ and streptomycin $(100 \mu \mathrm{g} / \mathrm{ml})$ (Life Technologies, Gaithersburg, MD, USA). Viability, as evaluated by Trypan Blue exclusion, was greater than $90 \%$. Finally, $10^{5}$ cells/well were seeded in 24-well tissue culture plates (Costar, Acton, MA, USA) coated with poly-D-lysine (Sigma) to minimize cell loss, and cultured in a metabolic incubator at $37^{\circ} \mathrm{C}$ with $5 \% \mathrm{CO}_{2}$ and $95 \%$ air for two days. Before the experiments, the cells were rinsed twice with serum-free Dulbecco's modified Eagle's medium and then incubated at $37^{\circ} \mathrm{C}$ in $5 \% \mathrm{CO}_{2}$ in $0.5 \mathrm{ml}$ of the same medium containing the appropriate test substances. After two hours incubation, conditioned medium was collected from each well, centrifuged at $14000 \mathrm{~g}$ for $5 \mathrm{~min}$, and stored at $-20{ }^{\circ} \mathrm{C}$ until assayed for PRL content. Attached cells were washed in PBS and fixed with $4 \%$ paraformaldehyde in $0.1 \mathrm{M}$ phosphate buffer, $\mathrm{pH} 7 \cdot 4$ for $30 \mathrm{~min}$. Following further rinsing, immunocytochemical procedures to identify PRLpositive cells were carried out as described above for tissue sections. Incubation of the cells with $1 \mu \mathrm{M}$ thyrotropin-releasing hormone (TRH) and $5 \mathrm{mM} \mathrm{8-Br-}$ cAMP (Sigma) for $1 \mathrm{~h}$ was used to stimulate secretion. All tests were done at least in triplicate in three independent experiments. PRL was determined by RIA using a National Pituitary Hormone Distribution Program (NIAMDD, Bethesda, MD, USA) rat hormone kit. The initial dilution of the antibody was 1:20 000. The double antibody method for separating the bound from the free fraction was used. Assay sensitivity was $3 \mathrm{ng} / \mathrm{ml}$, while the intra-assay and interassay variations were $3 \%$ and $10 \%$ respectively. Data were analyzed by the Mann-Whitney $\mathrm{U}$ test to identify which groups had significant differences.

\section{Results}

Exocytotic machinery in estrogen-induced tumoral pituitary cells

One week of treatment with $\mathrm{E}_{2}$ resulted in a significant increase in anterior pituitary weight $(30 \pm 2.82 \mathrm{mg}$ vs $12 \cdot 25 \pm 2.87 \mathrm{mg} ; P<0 \cdot 02$ ) and pituitary PRL (Fig. 1). These differences were dependent on the time course of $\mathrm{E}_{2}$ treatment (data not shown).

No differences were observed in the amount of $\mathrm{t}$ - and $\mathrm{v}$-SNAREs in brain homogenates from $\mathrm{E}_{2}$-treated rats 1 , 3 , and 6 weeks after surgery. Representative examples are shown in Fig. 2A. In striking contrast, the levels of all of these exocytotic proteins were notably decreased in total homogenates from pituitary glands of $\mathrm{E}_{2}$-treated animals at 


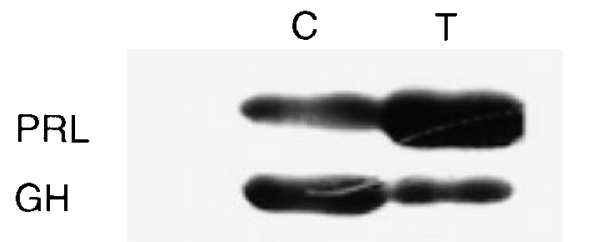

Figure 1 Western blotting analysis of PRL and $\mathrm{GH}$ in anterior pituitaries from control $(\mathrm{C})$ and $\mathrm{E}_{2}$-treated $(\mathrm{T})$ animals one week after surgery. Each lane was loaded with $10 \mu$ g protein.

any time analyzed (Figs $2 \mathrm{~B}$ and $3 \mathrm{~A}$ ). In addition, no changes were detected in the levels of the cytoskeletal component $\alpha$-tubulin, the plasma membrane $\mathrm{Na}^{+} / \mathrm{K}^{+}{ }_{-}$ ATPase, the SLMV marker synaptophysin, and the endosome marker linked to endocytotic pathway Rab5 (Gorvel et al. 1991) (Fig. 3B).

Immunocytochemical methods revealed that most of the pituitary cell population in the four-week $\mathrm{E}_{2}$-treated rats consisted of PRL-positive cells (Fig. 4A,B), whereas immunoreactive cells for the rest of the hormones constituted a small percentage (data not shown). We found a lower immunostaining intensity for all the exocytotic protein components analyzed in most of the endocrine cells from pituitary glands of $\mathrm{E}_{2}$-treated rats compared with controls. A representative immunostaining example is shown in Fig. 4C,D. Double-labeling immunocytochemistry showed a weak immunoreactivity for different exocytotic protein components in PRL-containing cells from $E_{2}$-treated animals compared with that found in

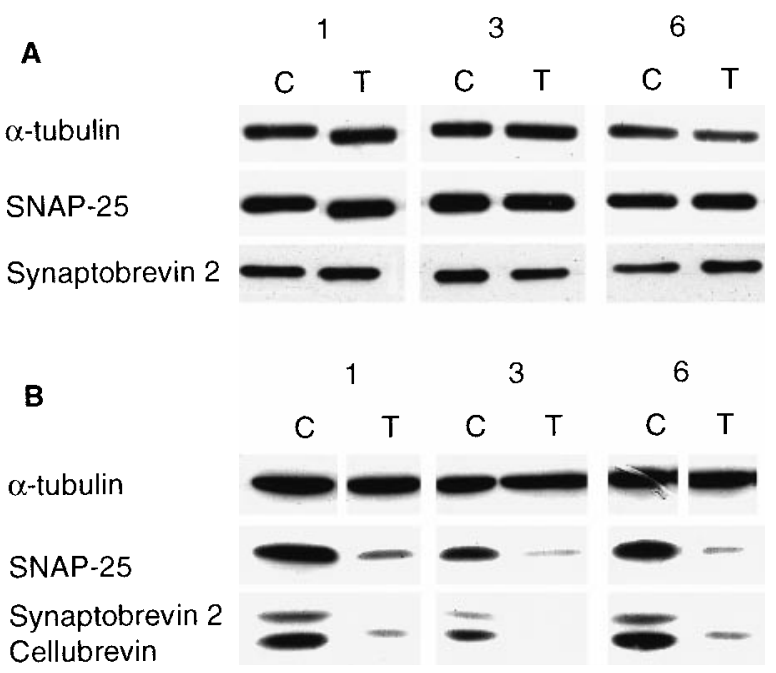

Figure 2 Western blotting analysis of $\alpha$-tubulin, SNAP-25, synaptobrevin 2 and cellubrevin from (A) brain and (B) pituitary of control $(\mathrm{C})$ and $\mathrm{E}_{2}$-treated $(\mathrm{T})$ rats 1,3 and 6 weeks after surgery. In (A) a specific antibody against synaptobrevin $2(18 \cdot 2)$ was used; in (B) an antibody against cellubrevin (CB35), which also recognizes its homolog synaptobrevin was used. Note the specific decrease of SNAP-25 and synaptobrevin 2/cellubrevin in pituitary glands of $E_{2}$-treated rats.
A

Synaptotagmin 1

\section{Syntaxin 1}

Rab3a

SNAP-25

Synaptobrevin 2 Cellubrevin

B

$\mathrm{Na} / \mathrm{K}$

$\alpha$-tubulin

Synaptophysin

Rab5

Figure 3 Western blotting analysis of different proteins from pituitary gland homogenates of control $(C)$ and $E_{2}$-treated $(T)$ rats 4 weeks after treatment. Several exocytotic proteins are decreased in pituitaries of $E_{2}$-treated rats $(A)$, whereas no changes are observed in the amount of other proteins (B).

PRL-containing cells from control animals (Fig. 5A-C). It is noteworthy that in addition to the common immunostaining pattern for SNAP-25, associated with the plasma membrane, luteinizing hormone ( $\mathrm{LH})$-containing cells from ovariectomized control animals consistently exhibited immunoreaction products for SNAP-25 in ring-shaped structures within the cells (Fig. 5D-F).

\section{$P R L$ secretion in $E_{2}$-treated pituitary in culture}

In an attempt to compare the PRL release rates between normal and $E_{2}$-treated cells, we analyzed the amount of PRL released per number of PRL immunostained cells in pituitary primary cell cultures from control and $\mathrm{E}_{2}$-treated animals seven weeks after surgery (Table 2). No differences were observed in the basal PRL release from 

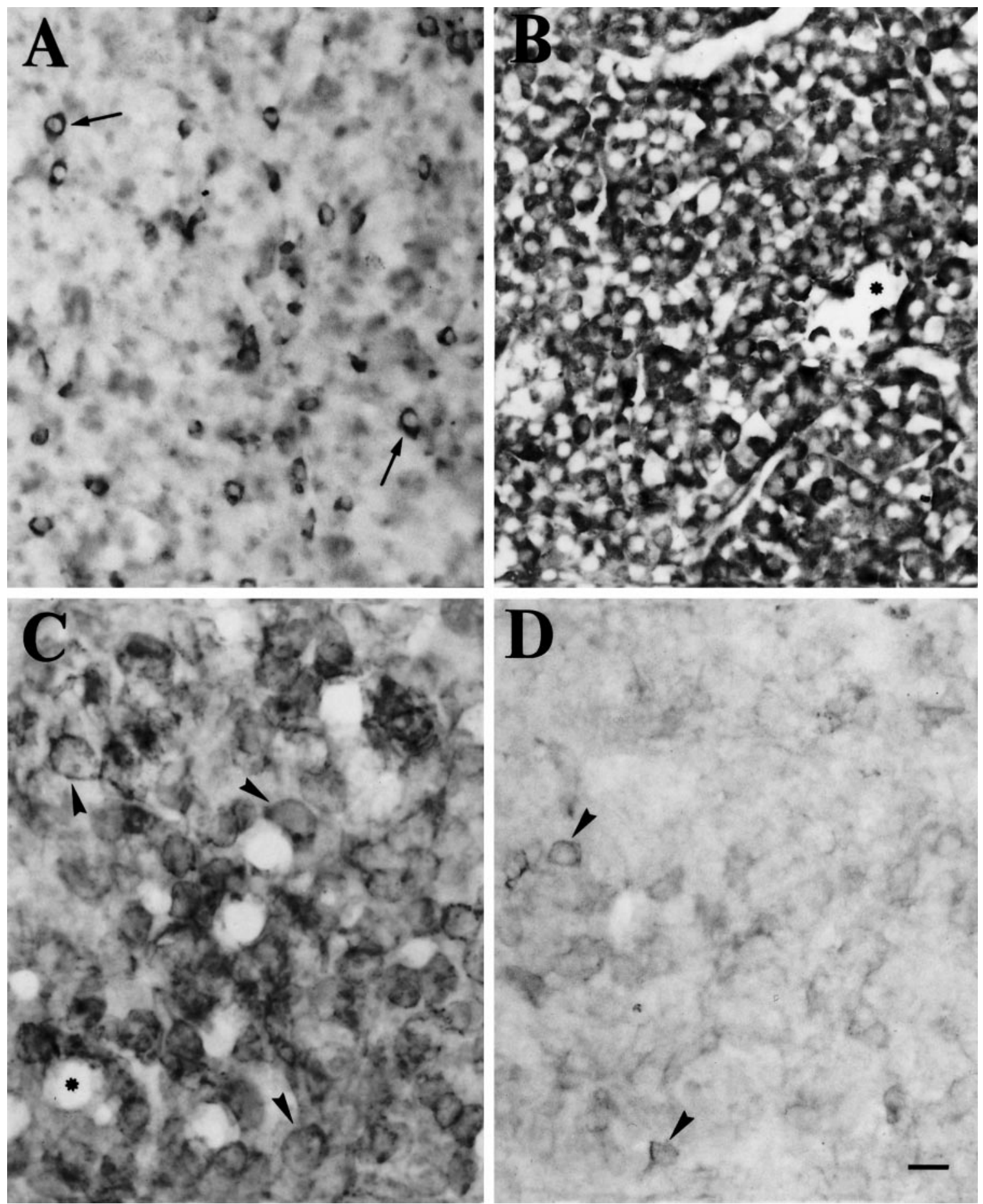

Figure 4 Photomicrographs of anterior pituitary sections of control $(A, C)$ and $E_{2}$-treated $(B, D)$ animals immunostained for PRL $(A, B)$ and SNAP-25 $(C, D)$. Note the increase in PRL-positive cells in pituitary glands of $E_{2}$-treated rats, whereas SNAP-25 is decreased. Arrows, PRL-positive cells; arrowheads, SNAP-25-positive immunostaining; asterisks, blood vessels. Scale bar: $20 \mu \mathrm{m}$. 

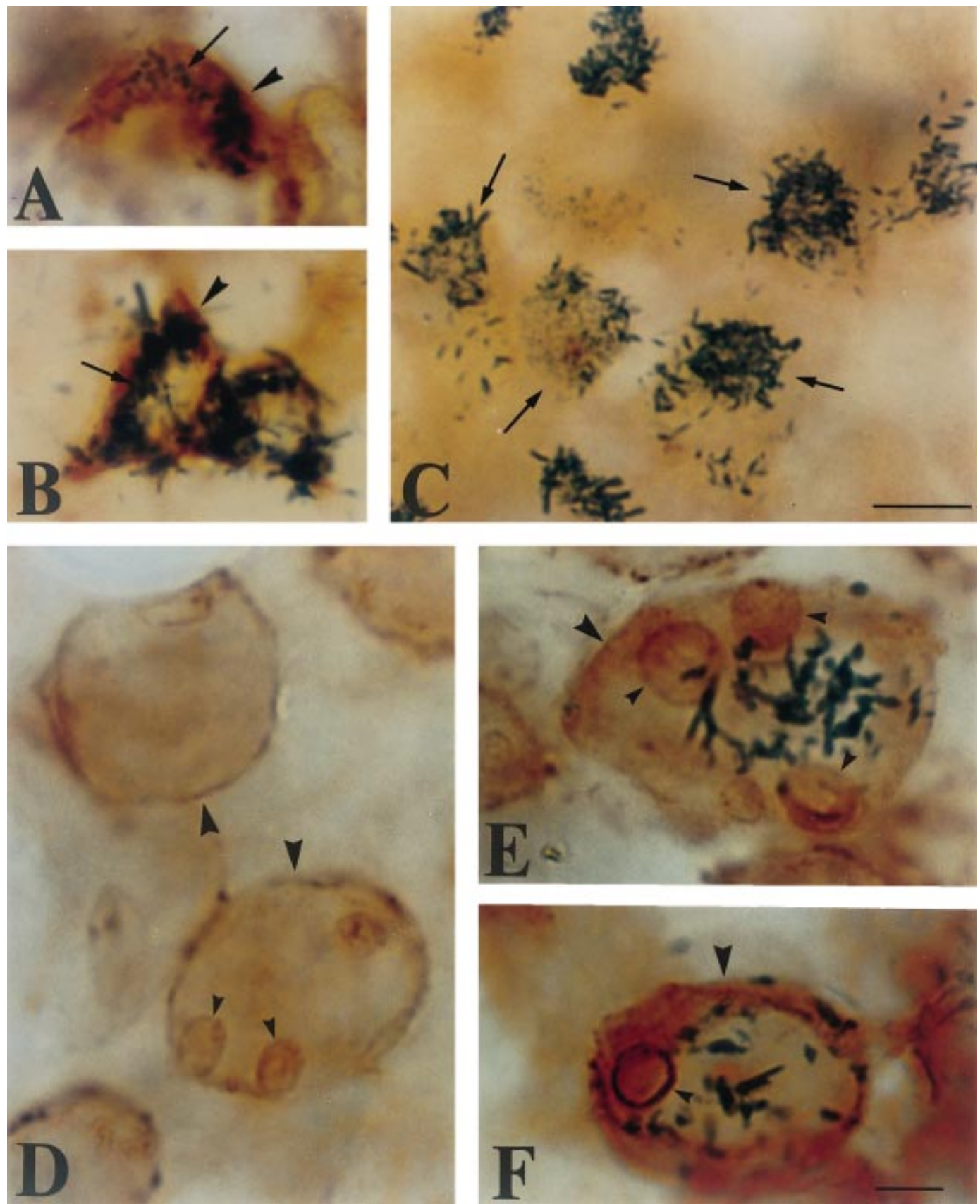

Figure 5 Double labeling immunocytochemistry of PRL (A-C) or LH (E,F) and SNAP-25 in control (A,B,D-F) and $\mathrm{E}_{2}$-treated (C) pituitary sections 4 weeks after treatment. In all illustrations, SNAP-25 was visualized as a brown precipitate at the plasma membrane. PRL and LH immunoreactivity was detected as a granular blue precipitate located in cytoplasmic areas. A-C, PRL-positive cells (arrows) from control animals exhibit SNAP-25 immunoreactivity (arrowheads) $(\mathrm{A}, \mathrm{B})$. In $\mathrm{E}_{2}$-treated pituitary, SNAP-25 immunostaining is near background in PRL-positive cells (arrows) (C). D-F, In addition to the plasma membrane (big arrowheads), SNAP-25 immunostaining is also located in ring-shaped structures within certain cells (small arrowheads) in ovariectomized control pituitary sections. Double labeling with $\mathrm{LH}(\mathrm{E}, \mathrm{F})$ reveals the gonadotrope identity. Scale bars: A-C, $30 \mu \mathrm{m} ; \mathrm{D}-\mathrm{F}, 10 \mu \mathrm{m}$. 
Table 2 PRL secretion from pituitary primary cell cultures of control and $\mathrm{E}_{2}$-treated rats. Basal (non stimulated, $\left.n=5\right)$ and 8-Br-cAMP ( $5 \mathrm{mM}, n=4)$ or TRH ( $1 \mu \mathrm{M}, n=4)$-induced PRL secretion was measured by RIA

PRL release (pg/lactotrope cell)

\begin{tabular}{|c|c|c|}
\hline & & \\
\hline & Median & Range \\
\hline Basal & & \\
\hline Control & $0 \cdot 41$ & $0 \cdot 272$ \\
\hline $\mathrm{E}_{2}$-treated & $0 \cdot 488$ & $0 \cdot 192$ \\
\hline 8-Br-cAMP & & \\
\hline Control & 0.595 & $1 \cdot 254$ \\
\hline $\mathrm{E}_{2}$-treated & $1 \cdot 084$ & $0 \cdot 319$ \\
\hline $\mathrm{TRH}$ & & \\
\hline Control & $0 \cdot 497$ & $0 \cdot 518$ \\
\hline $\mathrm{E}_{2}$-treated & $1 \cdot 712$ & $1 \cdot 821$ \\
\hline
\end{tabular}

8-Br-cAMP significantly stimulated PRL secretion from pituitary cells from both control and $\mathrm{E}_{2}$-treated rats $(P<0 \cdot 02)$ whereas TRH significantly stimulated PRL secretion from pituitary cells from $\mathrm{E}_{2}$-treated rats only $(P<0 \cdot 015)$.

pituitary cells of control and $\mathrm{E}_{2}$-treated rats. Incubation with the cAMP analog 8-Br-cAMP resulted in a similar increase in PRL secretion in cultured pituitary cells from control and $\mathrm{E}_{2}$-treated animals. The rate of TRH-induced PRL secretion in anterior pituitary cells from control rats was not increased. However, TRH had a notable effect on the rate of PRL secretion in pituitary cell cultures obtained from $\mathrm{E}_{2}$-treated animals (more than 3 times the basal secretion).

\section{Discussion}

In recent years, a group of protein components of the exocytotic machinery has been shown to be present in the rat anterior pituitary gland (Wendland \& Scheller 1994, Marquéze et al. 1995, Oho et al. 1995, Redecker et al. 1995, Aguado et al. 1996, Jacobsson \& Meister 1996, Majó et al. 1997, 1998). The amount and immunocytochemical location of all of these proteins shown in the present study agrees with previous reports. Interestingly, SNAP-25 immunoreactivity is also located in ring-shaped structures within gonadotrope cells from ovariectomized rats. Although the identity of these structures is still unknown, these may be related to the ultrastructural changes described in rat gonadotrope cells after ovariectomy (Garner \& Blake 1981). Future electron microscopic studies may shed light on this issue.

In this study we have shown that long-term $\mathrm{E}_{2}$ administration in F344 rats causes a decrease in SNAP-25, synaptobrevin 2, cellubrevin, syntaxin 1, synaptotagmin I, and Rab3a levels in the anterior pituitary gland. Since total brain homogenates show no differences in the levels of the exocytotic machinery component proteins after $\mathrm{E}_{2}$ treatment, the decrease observed in the pituitary gland of $\mathrm{E}_{2}$-treated animals seems to be specific. It has been shown that neonatal sex hormone manipulations can influence the expression of several synaptic proteins in the nervous system (Lustig et al. 1993). Administration of estrogen and estrogen inhibitor during the 'critical period' induces upand down-regulation respectively of SNAP-25 mRNA expression (Lustig et al. 1993). The present results showing a lack of change in SNAP-25 protein levels after $\mathrm{E}_{2}$ treatment in the adult brain may be related to the administration period. In addition, it is very likely that Western blotting analysis from whole brain homogenates could mask possible area-specific differences.

It is well established that long-term $\mathrm{E}_{2}$ administration in rats produces PRL-cell adenomas and chronic hyperprolactinemia (McEuen et al. 1936, Meyer \& Clifton 1956), with the F344 strain being particularly sensitive to developing $\mathrm{E}_{2}$-induced pituitary tumors (Dunning et al. 1947, Lloyd 1983, Phelps \& Hymer 1983). Ultrastructural examination of the $\mathrm{E}_{2}$-induced pituitary tumor cells reveals that most of them are sparsely granulated, suggesting a low storage capacity for these cells (Lloyd 1983, Hymer \& Motter 1988, G Majó, I Ferrer \& F Aguado (personal observations)). Recent reports have shown that most exocytotic proteins located on synaptic vesicles are also present in secretory granules and SLMV in anterior pituitary endocrine cells (Wendland \& Scheller 1994, Jacobsson \& Meister 1996, Majó et al. 1998). Interestingly, the levels of most of the proteins located on secretory organelles are decreased in pituitary cells of $\mathrm{E}_{2}$-treated rats, whereas no changes are observed for synaptophysin. Since synaptophysin is located exclusively on SLMV (Jahn \& De Camilli 1991, Majó et al. 1998), the decrease in the levels of synaptobrevin 2, cellubrevin, synaptotagmin I, and $\mathrm{Rab3a}$ in $\mathrm{E}_{2}$-treated pituitaries could reflect the low number of secretory granules in PRL cells of $E_{2}$-treated animals. In parallel with the levels of the exocytotic proteins present on secretory granules, the t-SNAREs, SNAP-25 and syntaxin 1 levels are also decreased in pituitary cells of $E_{2}$-treated rats. In agreement with this, a down-regulation of SNAP-25 expression in the rat pituitary has recently been shown after $\mathrm{E}_{2}$ administration (Jacobsson et al. 1998). On the other hand, it has been reported that SNAP-25 immunoreactivity is increased in human prolactinomas (Majó et al. 1997).

Since several exocytotic proteins have been shown to be essential for adenohypophyseal hormone release (Lledo et al. 1994, Aguado et al. 1997, Masumoto et al. 1997), the observed low levels of these proteins in the pituitaries of $\mathrm{E}_{2}$-treated rats may be correlated with the secretion rates. It has been established that the hyperprolactinemia observed in $\mathrm{E}_{2}$-treated animals is due to the increased number of PRL cells produced by lactotrope proliferation (Lloyd 1983) and recruitment of nonsecreting cells into an active PRL secreting pool (Boockfor et al. 1986, Scarbrough et al. 1991), as well as the $\mathrm{E}_{2}$-stimulated PRL synthesis (Scarbrough et al. 1991). Whether PRL release is increased or decreased in lactotropes from $\mathrm{E}_{2}$-treated 
animals is not well established yet. Our results show that neither the basal nor 8-Br-cAMP-induced PRL release in cultured cells from $\mathrm{E}_{2}$-treated animals differs from that in control donors. These results agree with a previous report showing no differences in basal PRL secretion between $\mathrm{E}_{2}$-induced adenoma and normal pituitaries, estimated by RIA (Yoshikawa et al. 1995). In addition, these authors found a smaller mean plaque area for $\mathrm{E}_{2}$-treated cells from F344 rats using the reverse hemolytic plaque assay (RHPA), suggesting a lower PRL release rate in $\mathrm{E}_{2}$ induced tumor cells (Yoshikawa et al. 1995). This observation could be in line with the low levels of exocytotic protein components detected in pituitary glands of $\mathrm{E}_{2^{-}}$ treated rats. However, by using the same RHPA technique, other authors found that PRL release is increased in cultured lactotropes from estrogen-primed rats (Kendall \& Hymer 1987, Lloyd et al. 1987, Zhang et al. 1990, Scarbrough et al. 1991). Although the meaning of these differences is unknown, they may be related to the rat strains and experimental conditions used.

We observed that TRH induced higher PRL secretion in cultured lactotropes from $\mathrm{E}_{2}$-induced tumors than in any other condition tested. In like measure, it has been shown that pretreatment with $\mathrm{E}_{2}$ enhances the TRH-stimulated PRL release in cultured rat lactotropes (Zhang et al. 1990, Scarbrough et al. 1991). The increased response to TRH observed in $\mathrm{E}_{2}$-treated animals could be related to an increase in the number of TRH receptors (Gershengorn et al. 1979) or alterations in the intracellular transduction signaling (Tang et al. 1982).

In conclusion, this study shows that protein components of the exocytotic machinery are down-regulated in the pituitary of $\mathrm{F} 344$ rats by $\mathrm{E}_{2}$ administration. The functional significance of the low exocytotic protein levels found in pituitary glands of $E_{2}$-treated animals within the exocytotic process remains to be elucidated.

\section{Acknowledgements}

We thank Dr A F Parlow (Bethesda, MD, USA) and the National Hormone and Pituitary Distribution Program (NIDDK, Bethesda, MD, USA) for the supply of pituitary hormone antisera and the rat PRL RIA kit, Dr R Jahn for his generous gift of antibodies against Rab3a, Rab5, synaptobrevin 2 and synaptotagmin I, and Dr C J Barnstable (New Haven, CT, USA) for syntaxin 1 antibody. We wish to thank Dr I Ferrer for useful comments and suggestions, and I Gomez de Aranda and E Laforet for their technical assistance. We are grateful to R Abost for statistics and Drs I Ferrer, L Cacicedo and T Fernandez for helpful discussion. We thank T Yohannan for editorial assistance. GM has a fellowship from Generalitat de Catalunya (Spain). This study was supported by a grant from DGICYT (PM95-0116) and by the EU project BMH4-CT96-1586.

\section{References}

Aguado F, Majó G, Ruiz-Montasell B, Canals JP, Casanova A, Marsal J \& Blasi J 1996 Expression of synaptosomal-associated protein SNAP-25 in endocrine anterior pituitary cells. European Journal of Cell Biology 69 351-359.

Aguado F, Gombau L, Majó G, Marsal J, Blanco J \& Blasi J 1997 Regulated secretion is impaired in AtT-20 endocrine cells stably transfected with botulinum neurotoxin type A light chain. Journal of Biological Chemistry 272 26005-26008.

Barnstable CJ, Hofstein R \& Akagawa K 1985 A marker for amacrine cells development in rat retina. Development Brain Research 20 286-290.

Ben-Jonathan N, Peleg E \& Hoefer MT 1983 Optimization of culture conditions for short-term pituitary cell culture. Methods in Enzymology 103 249-257.

Boockfor FR, Hoeffler JP \& Frawley LS 1986 Estradiol induces a shift in cultured cells that release prolactin or growth hormone. American Journal of Physiology 250 E103-E105.

Brose N, Petrenko AG, Südhof TC \& Jahn R 1992 Synaptotagmin: a calcium sensor on the synaptic vesicle surface. Science $\mathbf{2 5 6}$ 1021-1025.

Burgoyne HD \& Morgan A 1993 Regulated exocytosis. Biochemical Journal 293 305-316.

Dunning WF, Curtis MR \& Segaloff A 1947 Strain differences in response to diethylstilbestrol and the induction of mammary gland and bladder cancer in the rat. Cancer Research 7511.

Edelmann L, Hanson PI, Chapman ER \& Jahn R 1995 Synaptobrevin binding to synaptophysin: a potential mechanism for controlling the exocytotic fusion machine. EMBO Journal 14 224-231.

Fischer-von-Mollard G, Stahl B, Walch-Solimena C, Takei K, Daniels L, Khoklatchev A, DeCamilli P, Südhof TC \& Jahn R 1994 Localization of Rab5 to synaptic vesicles identifies endosomal intermediate in synaptic vesicles recycling pathway. European Journal of Cell Biology 65 319-326.

Garner LL \& Blake CA 1981 Ultrastructural, immunocytochemical study of the LH secreting cell of the rat anterior pituitary gland: changes occurring after ovariectomy. Biology of Reproduction 24 461-474.

Gershengorn MC, Marcus-Samuels BE \& Geras E 1979 Estrogens increase the number of thyrotropin-releasing hormone receptors on mammotrophs in culture. Endocrinology 105 171-176.

Gorvel JP, Chavrier P, Zerial M \& Gruenberg J 1991 rab5 controls early endosome fusion in vitro. Cell 64 915-925.

Hymer WC \& Motter KA 1988 Heterogeneity in mammotrophs prepared from diethylstilbestrol-induced prolactinomas. Endocrinology 122 2324-2338.

Jacobsson G \& Meister B 1996 Molecular components of the exocytotic machinery in the rat pituitary gland. Endocrinology 137 $5344-5356$

Jacobsson G, Razani H, Ogren SO \& Meister B 1998 Estrogen down-regulates mRNA encoding the exocytotic protein SNAP-25 in the rat pituitary gland. Journal of Neuroendocrinology 10 157-163.

Jahn R \& De Camilli P 1991 Membrane proteins of synaptic vesicles: markers for neurons and endocrine cells; tools for the study of neurosecretion. In Markers for Neural and Endocrine Cells, vol 14, pp 25-92. Eds M Gratzl \& K Langley. Weinheim: VCH.

Kendall ME \& Hymer WC 1987 Cell blotting: a new approach to quantify hormone secretion from individual rat pituitary cells. Endocrinology $1212260-2262$.

Kovacs K, Horvath E \& Ezrin C 1977 Pituitary adenomas. Pathology Annual 12 341-382.

Laemmli UK 1970 Cleavage of structural proteins during the assembly of the head of bacteriophage T4. Nature 227 680-685.

Lang J, Regazzi R \& Wollheim CB 1997 Clostridial toxins and endocrine secretion: their use in insulin-secreting cells. In Bacterial Toxins: Tools in Cell Biology, pp 217-240. Ed K Aktories. Weinheim: Chapman and Hall. 
Levey AI, Bolam JP, Rye DB, Hallanger AE, Demuth RM, Mesulam RM \& Wainer BH 1986 A light and electron microscopic procedure for sequential double antigen localization using diaminobenzidine and benzidine dihydrochloride. Journal of Histochemistry and Cytochemistry 34 1449-1457.

Linial M 1997 SNARE proteins: why so many, why so few? Journal of Neurochemistry 69 1781-1792.

Linial M \& Parnas D 1996 Deciphering neuronal secretion: tools of the trade. Biochimica et Biophysica Acta 1286 117-152.

Lledo PM, Vernier P, Vincent JD, Manson WT \& Zorec R 1993 Inhibition of $\mathrm{Rab} 3 \mathrm{~B}$ expression attenuates $\mathrm{Ca}^{2+}$-dependent exocytosis in rat anterior pituitary cells. Nature $364540-544$.

Lledo PM, Vernier P, Vincent JD, Manson WT \& Zorec R 1994 New approaches in the study of stimulus-secretion coupling in anterior pituitary cells. Annals of the New York Academy of Sciences 710 301-318.

Lloyd RV 1983 Estrogen-induced hyperplasia and neoplasia in the rat anterior pituitary gland. An immunohistochemical study. American Journal of Pathology 113 198-206.

Lloyd RV, Coleman K, Fields K \& Nath V 1987 Analysis of prolactin and growth hormone production in hyperplastic and neoplastic rat pituitary tissues by the hemolytic plaque assay. Cancer Research $\mathbf{4 7}$ 1087-1092.

Lustig RH, Hua P, Wilson MC \& Federoff HJ 1993 Ontogeny, sex dimorphism, and neonatal sex hormone determination of synapseassociated messenger RNAs in rat brain. Molecular Brain Research 20 101-110.

Majó G, Ferrer I, Marsal J, Blasi J \& Aguado F 1997 Immunocytochemical analysis of the synaptic proteins SNAP-25 and Rab3A in the human pituitary adenomas. Overexpression of SNAP-25 in the mammosomatotroph lineages. Journal of Pathology 183 440-446.

Majó G, Aguado F, Blasi J \& Marsal J 1998 Synaptobrevin isoforms in secretory granules and synaptic-like microvesicles in anterior pituitary cells. Life Sciences 62 607-616.

Marquéze B, Boudier JA, Mizuta M, Inagaki N, Seino S \& Seagar M 1995 Cellular localization of synaptotagmin I, II, and III mRNAs in the central nervous system and pituitary and adrenal glands of the rat. Journal of Neuroscience 15 4906-4917.

Masumoto N, Ikebuchi Y, Matsuoka T, Tasaka K, Miyake A \& Murata Y 1997 Involvement of SNAP-25 in TRH-induced exocytosis in pituitary GH4C1 cells. Journal of Endocrinology 153 R5-R10.

Matteoli M, Takei K, Cameron R, Hurlbut P, Johnston PA, Südhof TC, Jahn R \& DeCamilli P 1991 Association of Rab3A with synaptic vesicles at late stages of the secretory pathway. Journal of Cell Biology 115 625-633.

McEuen CS, Selye H \& Collip JB 1936 Some effects of prolonged administration of oestrin in rats. Lancet 1 775-776.

Meyer RK \& Clifton KH 1956 Effect of diethylstilbestrol-induced tumorigenesis on the secretory activity of the rat anterior pituitary gland. Endocrinology 58 686-693.

Morgan A \& Burgoyne RD 1997 Common mechanism for regulated exocytosis in the chromaffin cell and the synapse. Seminars in Cell and Development Biology 8 141-149.
Nsee JK, Fleming AM \& Scheller RH 1993 A rab protein regulates the localization of secretory granules in AtT-20 cells. Molecular Biology of the Cell 4 747-756.

Oho C, Seino S \& Takahashi M 1995 Expression and complex formation of soluble N-ethyl-maleimide-sensitive factor attachment protein (SNAP) receptors in clonal endocrine cells. Neuroscience Letters 186 208-210.

Perez F, Lledo PM, Karagogeos D, Vincent JD, Prochiantz A \& Ayala J 1994 Rab3A and Rab3B carboxy-terminal peptides are both potent and specific inhibitors of prolactin release by rat cultured anterior pituitary cells. Molecular Endocrinology 8 $1278-1287$.

Phelps C \& Hymer WC 1983 Characterization of estrogen-induced adenohypophyseal tumors in the Fischer 344 rat. Neuroendocrinology 37 23-31.

Redecker P, Cetin Y \& Grube D 1995 Differential distribution of synaptotagmin I and rab3 in the anterior pituitary of four mammalian species. Neuroendocrinology 62 101-110.

Rothman JE 1994 Intracellular membrane fusion. Advances in Second Messenger Phosphoprotein Research 29 81-96.

Scarbrough K, Weiland NG, Larson GH, Sortino MA, Chiu S, Hirshfield AN \& Wise PM 1991 Measurement of peptide secretion and gene expression in the same cell. Molecular Endocrinology $\mathbf{5}$ 134-142.

Söllner T, Bennet MK, Whiteheart SW, Scheller RH \& Rothman JE 1993a A protein assembly-disassembly pathway in vitro that may correspond to sequential steps of synaptic vesicles docking, activation, and fusion. Cell 75 409-418.

Söllner T, Whiteheart SW, Brunner M, Erdjument-Bromage H, Geromanos S, Tempst P \& Rothman JE 1993b SNAP receptors implicated in vesicle targeting and fusion. Nature 362 318-324.

Südhof TC 1995 The synaptic vesicle cycle: a cascade of proteinprotein interactions. Nature 375 645-653.

Tang LK, Martellock AC \& Tang FY 1982 Estradiol stimulation of pituitary cAMP production and cAMP binding. American Journal of Physiology 243 E109-E113.

Towbin H, Staehelin T \& Gordon J 1979 Electrophoretic transfer of proteins from polyacrylamide gels to nitrocellulose sheets: procedure and some applications. Proceedings of the National Academy of Sciences of the USA 76 4350-4354.

Wendland B \& Scheller R 1994 Secretion in AtT-20 cells stably transfected with soluble synaptotagmins. Molecular Endocrinology 8 1070-1082.

Yoshikawa M, Uozumi T, Kawamoto K, Arita K, Ito A \& Takahashi S 1995 Characteristics of prolactin secretion in normal and estrogen-treated pituitaries of rats at the single cell level: analysis by reverse hemolytic plaque assay. Endocrine Journal 42 235-243.

Zhang J, Chen C, Kukstas LA, Vincent JD \& Israel JM 1990 Functional lactotroph heterogeneity in lactating rats and in vitro modification by $17 \beta$-estradiol. Journal of Neuroendocrinology 2 815-823.

Received 24 June 1998

Accepted 20 November 1998 